\title{
К ВОПРОСУ ОБ АЛГОРИТМЕ ДЕЙСТВИЙ СЛЕДОВАТЕЛЯ ПРИ ПРОИЗВОДСТВЕ ПО УГОЛОВНОМУ ДЕЛУ С ИНОСТРАННЫМ ЭЛЕМЕНТОМ
}

Аннотация: В статье анализируются проблемы участия иностранных граждан в уголовном процессе. Последовательно рассматриваются формы, в которых иностранцы принимают участие в российском уголовном прочессе и те практические проблемы, которые возникают в связи с этим в деятельности следователя. В основу статьи легли результаты эмпирического метода исследования опроса следователей и адвокатов, имевших опыт работы по делам с участием иностранцев. На этом основании автор делает вывод о необходимости внесения изменений в Уголовно-процессуальный кодекс, а также предлагает алгоритм действий следователя при производстве по уголовным делам с участием иностранных граждан, целью которого является реализация их прав и законных интересов. Общенаучные: анализ, синтез; эмпирические: описание, анкетирование; частнонаучные: формально-юридический, конкретно-правовой, логико-юридический, нормативно-юридический, доктринального толкования, аналогии закона и права. В статье впервые предпринимается попытка выработать алгоритм действий практического работника (следователя), по реализации предусмотренных Уголовно-процессуальным кодексом прав и законных интересов иностранных граждан, участвующих в российском уголовном процессе. Анализ практики позволяет автору говорить о том, что законодатель определяет в тексте закона права иностранца-участника процесса, однако не конкретизирует, как следователь должен реализовывать их. На практике это порождает ряд проблем, которые следователь вынужден решать всякий раз заново, в отсутствие чётких законодательных указаний. Это приводит к нарушениям прав и законных интересов иностранных граждан. Автор предлагает внести изменения в текст Уголовно-процессуального кодекса, а также алгоритм действий следователя, который может быть использован в практической работе.

Ключевые слова: иностранные граждане, следователь, международный договор, переводчик, дипломатический иммунитет, принцип языка, принципы уголовного судопроизводства, участники уголовного судопроизводства, международное сотрудничество, консульский иммунитет.

DOI: 10.7256/1994-1471.2014.5.11066

$\mathrm{H}$ есмотря на все изменения, происходившие в России после распада СССР и до настоящего времени, положения Уголовно-процессуального кодекса (далее - УПК) об иностранцах не претерпевали изменений с 1960-х годов. В тот момент преступления «с иностранным элементом» в нашей стране почти отсутствовали и законодатель, определяя порядок участия иностранцев в уголовном процессе, ограничился лишь несколькими очень лаконичными формулировками. Поскольку иностранцев в СССР проживало крайне мало, практических проблем это не порождало.

Сегодня ситуация полностью изменилась. Иностранцы постоянно попадают в сферу деятельности органов уголовного преследования, а положения УПК, определяющие действия

следователя по делу с участием иностранного гражданина, отсутствуют. В итоге, поиск переводчика, взаимодействие с посольством (консульством), производство следственных действий, взаимодействие с правоохранительными органами иностранного государства в порядке международного сотрудничества превращаются в проблему, которую следователь должен решать раз за разом как бы «с чистого листа», в отсутствие четких указаний законодателя.

Решаться эта проблема должна, во-первых, на уровне положений УПК и их переработки, во-вторых, на межотраслевом уровне.

Для того чтобы ответить на вопрос о том, каковы должны быть действия следователя, дознавателя, прокурора, суда, если участником процесса становится иностранный гражданин,

(C) Шестакова Татьяна Дмитриевна

* Ассистент кафедры уголовного процесса и криминалистики, Самарский государственный университет

[tatiana.law@yandex.ru]

443011, Россия, г. Самара, ул. Академика Павлова, д. 1. 
необходимо проанализировать, в каких формах иностранцы участвуют в российском уголовном процессе и какие основные проблемы при этом возникают.

На практике иностранные граждане чаще всего принимают участие в уголовном процессе в качестве обвиняемых (подозреваемых) и потерпевших, а также свидетелей. Кроме того, УПК не содержит запрета для участия иностранца как специалиста, переводчика, понятого, законного представителя, адвоката.

С того момента, как только иностранный гражданин приобретает процессуальный статус, это порождает ряд специфических задач для следователя (дознавателя), а затем - и для суда. Для того, чтобы их выделить, необходимо рассмотреть, как иностранец приобретает свой процессуальный статус.

Подозреваемый (обвиняемый)-иностранный гражданин может «появиться» в российском уголовном процессе несколькими путями:

1. Возбуждение уголовного дела в РФ в отношении иностранного гражданина: по инициативе российских органов уголовного преследования либо по инициативе иностранного государства;

2. Возбуждение уголовного дела в иностранном государстве и направление в РФ запроса о розыске или производстве следственных действий, или запроса о выдаче, или запроса о применении меры пресечения для исполнения запроса о выдаче.

В случае если уголовное преследование в отношении иностранца возбуждается российским следователем (дознавателем) в момент, когда устанавливается личность гражданина, следователь получает информацию о том, что перед ним - гражданин зарубежного государства. По общему правилу, она должна быть подтверждена документально (паспорт, заграничный паспорт, миграционная карта и т.д.). Однако если документы у гражданина отсутствуют, например, были утеряны или украдены, на практике уже на этом этапе следователь впервые взаимодействует с посольством (консульством) государства гражданства иностранца.

Исходя из положений ст. 3 УПК, следователь должен установить факт, обладает ли иностранец дипломатическим или консульским иммунитетом, исключающим его уголовное преследование.

В случае если он отсутствует, исходя из содержания п. 3 ст. 1 УПК, следователь должен выяснить, какие международные договоры заключены между РФ и государством гражданства лица. Множество двусторонних международных договоров и соглашений, заключенных РФ почти со всеми государствами мира, содержат положения, определяющие специфические права граждан соответствующих государств в российском уголовном процессе. В УПК эти положения чаще всего не находят своего отражения. Исходя из содержания ст. 1 УПК, как только в уголовном процессе появляется участник-иностранец, задача следователя реализовать его права, предусмотренные не только УПК, но и международными договорами с государством его гражданства. Однако на практике этого не происходит в абсолютном большинстве случаев. В ходе исследования были опрошены 37 следователей Следственного управления Следственного комитета Российской Федерации по Самарской области. При этом опрашивались только те, в производстве которых было более трех уголовных дел с участием иностранных граждан. Кроме того, были опрошены 52 адвоката Палаты адвокатов Самарской области, в практике которых было более трех уголовных дел, по которым они выступали в качестве защитников или представителей иностранных граждан. На соответствующий вопрос анкеты 100\% опрошенных следователей (37 человек) ответили, что не обращаются к положениям международных договоров при работе по делам с участием иностранных граждан. Все опрошенные поясняли, что в своей деятельности руководствуются лишь УПК. Причем, это происходит и при направлении запросов о правовой помощи в иностранное государство, которые согласно ст. 453 УПК направляются «в соответствии с международным договором Российской Федерации, международным соглашением или на основе принципа взаимности».

Среди опрошенных адвокатов аналогичный ответ дали $71 \%$ (37 адвокатов из 52), из чего можно сделать вывод, что и защитники не требуют от следователей такой формы обеспечения прав и законных интересов для своих подзащитных.

Таким образом, обязанность следователя руководствоваться в своей деятельности нормами международного права, прямо не определенная в УПК, но вытекающая из ст. 1, на практике фактически не работает.

При первом же допросе следователь обязательно задает подозреваемому (обвиняемому), потерпевшему, свидетелю, независимо от их гражданства, вопрос, владеют ли они русским языком и нуждаются ли в помощи переводчика. В случае если гражданин заявляет, что русским языком не владеет, на следователя ложится обязанность поиска переводчика.

УПК не обязывает следователя контактировать с посольством (консульством) иностранного гражданина за исключением уведомления о его задержании, предусмотренного ст. 96 
УПК. На практике и при задержании посольство (консульство) уведомляется не всегда. Лишь $62 \%$ опрошенных следователей (23 человека из 37) на соответствующий вопрос ответили, что связывались с посольством (консульством) государства, гражданин которого был ими задержан. На практике, сами посольства (консульства) далеко не всегда проявляют интерес к судьбе своего гражданина, попавшего в сферу деятельности органов уголовного преследования, хотя это является их обязанностью. Со своей стороны, именно они должны обеспечивать защиту своего гражданина за рубежом и для достижения этих целей могли бы оказать содействие в поиске, например, квалифицированного переводчика. Для этого посольства (консульства) обладают явно большими возможностями, чем следователь, и сотрудничество в этом вопросе могло бы обеспечить гораздо лучшую защиту прав и законных интересов иностранных граждан в процессе.

Зафиксировать положение о сотрудничестве посольских (консульских) учреждений с органами уголовного преследования РФ в целях наиболее полного обеспечения прав и законных интересов иностранных граждан в российском уголовном процессе представляется возможным только на уровне международных договоров и соглашений. Такое сотрудничество представляется необходимым и прямо вытекающим из обязанности государства покровительствовать своим гражданам за рубежом.

Одним из специфических вариантов возбуждения уголовного дела в отношении иностранного гражданина является возбуждение дела по инициативе - запросу о правовой помощи или по информации - иностранного государства. Эта ситуация возникает, когда компетентные органы иностранного государства имеют информацию о совершении преступления, но не имеют возможности возбудить уголовное дело самостоятельно - например, преступник вместе с уликами скрылся на территории России. Возможна и обратная ситуация, когда российские правоохранительные органы располагают информацией о совершении преступления и предоставляют ее иностранному государству. Причем на практике источником этой информации не всегда становятся органы, осуществляющие уголовное преследование. Например, в 2011 году в Самарской области граждане Китайской народной республики (КНР) совершили убийство двух граждан Таджикистана, совместно с которыми они работали в фермерском хозяйстве, похитили личные вещи убитых и скрылись на территории КНР. По данному факту было возбуждено уголовное дело, однако оно осталось нераскрытым, запрос о правовой помощи следователь не на- правил. Тогда органы местного самоуправления - администрации муниципального района, на территории которого было совершено преступление, направили информацию о совершенном преступлении правоохранительным органам КНР. В течение двух последующих месяцев следственные органы КНР возбудили уголовное дело, задержали виновных лиц, обнаружили у них личные вещи убитых. Виновные были осуждены и приговор (высшая мера наказания - расстрел) был приведен в исполнение, российские компетентные органы - уведомлены об этом. Таким образом, информация, полученная от государственных органов, стала основанием для возбуждения уголовного дела на территории зарубежного государства и помогла быстрому раскрытию преступления, совершенного на территории России. Подобные случаи в практике нередки, однако, в соответствии с УПК с запросом о правовой помощи должен обращаться следователь, в противном случае, иные органы государственной власти и местного самоуправления фактически выполняют его обязанности.

В случае если уголовное дело возбуждается на территории иностранного государства и в Россию направляется запрос о правовой помощи, по общему правилу уголовное дело российский следователь не возбуждает, а проводит следственные действия во исполнение направленного запроса. Исключение составляет ситуация, когда в ходе исполнения запроса следователь получает информацию об ином преступлении, совершенном на территории РФ или зарубежного государства. В этом случае будет возбуждено уголовное дело.

Помимо подозреваемых (обвиняемых), иностранные граждане участвуют в российском уголовном процессе и в качестве иных участников процесса. Органы предварительного расследования часто используют иностранцев в качестве понятых и переводчиков. Не имея возможности или желания искать понятого или переводчика, следователь использует в этом качестве задержанных граждан - например, других иностранцев, представителей той же национальности, что и обвиняемый (подозреваемый), владеющих русским языком лучше, чем он. Это могут быть и задержанные вместе лица, ранее знакомые друг с другом. На вопрос анкеты «Привлекали ли Вы в качестве переводчика задержанных лиц, владеющих как нужным иностранным языком, так и русским?» 81\% опрошенных следователей, в производстве которых были дела с иностранным элементом (30 следователей из 37), ответили положительно, 5,4\% (2 следователя) отказались отвечать на вопрос. На вопрос «При производстве по делам с участием ино- 
странных граждан привлекали ли Вы в качестве понятых других иностранных граждан - представителей той же национальности?» 84\% опрошенных (31 человек из 37) ответили положительно. Такую практику следует считать прямым нарушением прав и законных интересов всех участников процесса. В распространенном случае, когда в качестве переводчика приглашают другого задержанного, говорить о качестве перевода, а, следовательно, о достоверности полученных таким образом доказательств, невозможно. В случае если аналогично привлекают понятого, очень велик риск его необъективности и, как следствие, утраты доказательства. В качестве примера можно привести случай, когда при производстве по делу о хищении, подозреваемым был рабочий со стройки, гражданин Узбекистана, а в качестве понятого следователь привлек другого гражданина Узбекистана, работавшего на той же стройке. В суде понятой, желая облегчить участь земляка, начал опровергать все факты, которые ранее удостоверял. Пункт 2 ст. 72 УПК содержит запрет на участие в качестве понятого лишь близких родственников-участников процесса. Однако желание помочь земляку в чужой стране зачастую может быть не менее сильным, чем желание помочь родственнику, и может так же серьезно повлиять на действия понятого и породить реальные проблемы на практике. Дополнив ст. 72 запретом участия в качестве понятых иностранных граждан - можно было бы решить эти проблемы. УПК не содержит запрета и для привлечения иностранцев в качестве специалистов. Это положение представляется оправданным, т.к. в процессе может возникнуть необходимость привлечения лиц, обладающих специальными знаниями в редких областях науки, культуры, искусства, которых может не быть в нашей стране.

Еще одна особая категория иностранных граждан - лица, обладающие дипломатическим (консульским) иммунитетом. Соответствующие права предоставлены этим лицам международными нормативными актами Венской конвенцией о дипломатических сношениях $1961^{1}$ г., Венской Конвенцией о специальных миссиях $1969^{2}$ г. и др. Однако они содержат лишь общие положения. Вопросы практической реализации Конвенции определяются двусторонними договорами, какой-либо единой модели на этот счет не существует.

Венская конвенция о дипломатических сношениях 1961 г. // Ведомости СССР. 1964. № 18. Ст. 221.

Венская конвенция о специальных миссиях 1969 г. // Международное публичное право / Сборник документов / сост. К.А. Бекяшев, А.Г. Ходаков. М., 1996. C. 209-221.
Это приводит к тому, что круг лиц и объем этих иммунитетов определяются всякий раз по-разному. Например, по некоторым конвенциям (ст. 1 Консульской конвенции между СССР и США 1964 г., ст. 1 Консульской конвенции между СССР и Французской Республикой $1966 \Gamma^{4}$ ) к консульским должностным лицам относятся также стажеры - лица, прикомандированные к консульскому учреждению для обучения консульской службе. Статья 5 Консульского договора между СССР и ФРГ 1958 г. к числу должностных лиц относит также секретарей и референтов, уполномоченных на осуществление определенных должностных консульских функций, фамилии которых сообщены в этом качестве государству пребывания консула. В соглашениях с иными иностранными государствами этот круг субъектов не обозначен как обладающий иммунитетами.

В некоторых случаях полным иммунитетом от уголовной юрисдикции РФ пользуются лишь главы консульских учреждений (ст. 10 Консульской конвенции между СССР и Королевством Бельгии $1972 \Gamma^{5}$ ) или главы учреждений и члены их семей (ст. 15 Консульской конвенции между СССР и Королевством Норвегии 1971 г. $^{6}$ ). Иногда консульские должностные лица и сотрудники консульского учреждения, являющиеся гражданами аккредитующего государства, не подлежат юрисдикции РФ лишь в том, что касается их служебной деятельности (ст. 15 Консульской конвенции между СССР и Мексиканскими Соединенными Штатами 1978 г.7).

Фактически, каждый двусторонний договор по-разному определяет порядок реализации иммунитета. В практическом плане, для следователя (дознавателя) это означает необходимость всякий раз обращаться к тексту соответствующего двустороннего договора, не ограничиваясь лишь положениями Конвенции. В действительности этого не происходит в абсолютном большинстве случаев.

Можно сделать вывод, что участие в процессе иностранца порождает ряд обязанностей

Консульская конвенция между СССР и США 1964 г. // СДД СССР. Вып. ХХV. М., 1972. С. 81-91.

4 Консульская конвенция между СССР и Французской Республикой 1966 г. // СДД СССР. Вып. XXVI. М., 1973. С. $77-87$.

Консульская конвенция между СССР и Королевством Бельгии 1972 г. // СДД СССР. Вып. ХХХІ. М., 1977. С. $65-79$.

Консульская конвенция между СССР и Королевством Норвегии 1971 г. // СДД СССР. Вып. ХХХ. М., 1976. С. 77-89.

Консульская конвенция между СССР и Мексиканскими Соединенными Штатами 1978 г. // СДД СССР. Вып. XXXV. М., 1981. С. 106-117. 
для следователя. Они прямо не зафиксированы в УПК, но прямо следуют из него. Фактически, это те действия, от выполнения которых зависит, будут ли реализованы положения УПК, его принципы, права и обязанности участников процесса, или нет.

1. Реализация принципа языка уголовного судопроизводства (ст. 18 УПК РФ)

Прежде всего, следователь (дознаватель) выясняет, какими языками владеет иностранец и нуждается ли он в помощи переводчика. Если гражданин не владеет русским языком, главная задача следователя - найти переводчика, так как без его участия никакую иную информацию получить невозможно. Без реализации принципа языка, права пользоваться родным языком и помощью переводчика реализовать все остальные принципы уголовного судопроизводства и права всех участников процесса невозможно.

2. Реализация приоритета общепризнанных принципов и норм международного права (п. 3 ст. 1 УПК РФ)

Затем следователь устанавливает, гражданином какого именно государства является данный иностранный гражданин и является ли он сотрудником посольства (консульства). Это также происходит на первом же этапе взаимодействия следователя (дознавателя) с ним, в рамках установления личности гражданина. Установив, гражданство какого государства имеет иностранец, следователь (дознаватель) должен выяснить, какие международные договоры между РФ и данным иностранным государством существуют, т.к. двусторонний международный договор нередко определяет права и обязанности граждан в уголовном процессе, и п. 3 ст. 1 УПК обязывает руководствоваться ими в первую очередь по отношению к положениям УПК. 3. Обеспечение подозреваемому и обвиняемому права на защиту (ст. 16 УПК РФ).

3.1. Согласно п. 3 ст. 96 УПК «Уведомление о задержании подозреваемого», «если подозреваемый является гражданином или подданным другого государства, то в срок, указанный в части первой настоящей статьи, уведомляется посольство или консульство этого государства».

Законодатель обязывает следователя уведомлять посольство (консульство) о задержании иностранца с той же целью, с которой иные положения этой статьи обязывают уведомлять близких родственников лица и т.д. Основная цель этого - обеспечить задержанному, находящемуся в условиях ограниченной свободы, права на защиту, которое самостоятельно реализовать он не может. Фактически, его право на защиту - поиск адвоката, заключение договора с ним, иные действия, - с этого момента реализовывают лица, подлежащие уведомлению. Применительно к иностранному гражданину - это посольство (консульство), представляющее государство его гражданства, обладающее соответствующими обязательствами по отношению к своему гражданину. В связи с этим является целесообразным и предложение об обращении к посольству (консульству) о помощи в поиске переводчика. 